\title{
The Review
}

\section{First do no harm:}

\section{practising holistically}

First Do No Harm is a series of 12 brief monthly articles with internet footnotes about harming and healing in general practice. Each article is based on one of the 12 RCGP competency domains, this month's being:

2. Practising holistically: the ability of the doctor to operate in physical, psychological, socioeconomic, and cultural dimensions, taking into account feelings as well as thoughts.

'Few would deny that fear may become or engender disease. It might almost be described as the great pandemic malady. I have alternatively referred to it as one of the two great primary symptoms. Pain is the other one. They are, in fact, what our patients chiefly bring to us. ${ }^{2}$

\section{INTRODUCTION}

Practising holistically isn't an option but a necessity: ${ }^{3}$ medical-model disease and functional illness co-exist and interweave and the division between disease and dysfunction is a construct - it exists in the doctor's mind, not in the patient's body. ${ }^{4}$

\section{HARMING}

Casting the patient as victim or villain and the doctor as rescuer.' Helping the patient to rehearse and reinforce past mental trauma. ${ }^{5}$ Oscillating between indulgence and punishment. ${ }^{6}$

\section{HEALING}

Casting the patient as a protagonist, asking what factors have made them ill and what factors can make them better,? validating what the patient offers, giving a physical explanation that doesn't blame and offers them control, ${ }^{8}$ talking about mechanism rather than cause. ${ }^{9}$ Witnessing, holding figuratively, ${ }_{10}^{10}$ and touching physically. ${ }^{11}$ Using the impact of symptoms on a patient's life as a prompt to action while using medical knowledge as guide to the type of action taken. Tempering the urge to comfort with pharmaceutical judgement. ${ }^{4}$

\section{ATTITUDE}

Being prepared to shoulder a disproportionate share of the burden of sustaining a relationship with the many consulters for whom relationships are difficult. ${ }^{4}$

\section{KNOWLEDGE}

Among 10 people aged $18-60$ years in the UK, in the previous 2 weeks, two to four have experienced tiredness, anxiousness, depression, indigestion, headache, back pain, or joint pain. ${ }^{12}$ Among 10 patients consulting UK GPS, three or four have a personality disorder. ${ }^{13,14}$ Negative feelings, actions, and words are clues to people's positive needs..$^{15}$ After an unpleasant event, immersing and focusing on feelings is unhelpful while distancing and explaining are helpful..$^{16}$ The majority of patients would feel comforted if touched appropriately by their doctor. ${ }^{11}$

\section{SKILLS}

Constantly revising the diagnosis. ${ }^{10}$ Moving from the negative to the positive, from what can't be done to what can be done, from areas of disagreement to areas of agreement; adopting a professional stance, providing clear explanations, tolerating odd beliefs and behaviours, maintaining a therapeutic detachment. ${ }^{6}$ Helping patients cope with adverse events by distancing themselves emotionally and finding explanations that make sense of the experience. ${ }^{16}$ After a confrontation, rapidly offering reconciliation followed by an attempt at cooperation. ${ }^{17}$

\section{Wilfrid Treasure,}

GP, Whalsay Health Centre, Symbister, Whalsay, Shetland.

\section{Provenance}

Commissioned; not peer reviewed.

\section{DOI: 10.3399/bjgp12X652409}

\section{Supplementary information}

The internet footnotes accompanying this article can be found at:

http://unw.darmipc.net/first-do-no-harm-footnotes.html

\section{ADDRESS FOR CORRESPONDENCE}

\section{Wilfrid Treasure}

Whalsay Health Centre, Symbister, Whalsay, Shetland ZE2 9AE, UK.

E-mail: doctorwilfridtreasureagmail.com

\section{REFERENCES}

1. Royal College of General Practitioners. nMRCGP 12 competency areas in detail. London: RCGP. http://www.rcgp.org.uk/docs/nMRCGP_12 Competency Areas in detail.doc laccessed 6 Jun 2012).

2. Ryle JA. The natural history of disease. 2nd edn. Oxford: Oxford University Press, 1948.

3. Balint M, (ed.). Treatment or diagnosis: a study of repeat prescriptions in general practice. London: Tavistock Publications, 1970

4. Treasure W. Diagnosis and risk management in primary care: words that count, numbers that speak. Abingdon: Radcliffe Publishing, 2011.

5. Meador CK. Symptoms of unknown origin. Nashville, TN: Vanderbilt University Press, 2005.

6. Ward RK. Assessment and management of personality disorders. Am Fam Physician 2004 70(8): 1505-1512.

7. Antonovsky A. Health, stress, and coping. San Francisco, CA: Jossey-Bass, 1979

8. Salmon P, Peters S, Stanley I. Patients perceptions of medical explanations for somatisation disorders: qualitative analysis. $B M$ 1999; 318(7180): 372-376.

9. Stone J. Functional and Dissociative Neurological Symptoms: a patient's guide. http://www.neurosymptoms.org/ laccessed 6 Jun 2012).

10. Cocksedge S, Greenfield R, Nugent GK, Chew Graham C. Holding relationships in primary care: a qualitative exploration of doctors' and patients' perceptions. Br J Gen Pract 2011; DOI: 10.3399/bjgp11X588457.

11. Singh $\mathrm{C}$, Leder $\mathrm{D}$. Touch in the consultation. $\mathrm{Br} J$ Gen Pract 2012; 62(596): 147-148.

12. McAteer A, Elliott AM, Hannaford PC Ascertaining the size of the symptom iceberg in a UK-wide community-based survey. $\mathrm{Br} \mathrm{J}$ Gen Pract 2011; DOI: 10.3399/bjgp11X548910.

13. Moran $P$, Jenkins $R$, Tylee $A$, et al. The prevalence of personality disorder among UK primary care attenders. Acta Psychiatr Scand 2000; 102(1): 52-57.

14. Alwin N, Blackburn R, Davidson K, et al. Understanding personality disorder: a report by the British Psychological Society. Leicester: The British Psychological Society, 2006

15. Rosenberg MB. Nonviolent communication: a language of life. Encinitas, CA: PuddleDancer Press, 2003.

16. Wilson TD. Redirect: the surprising new science of psychological change. London: Little Brown, 2011.

17. Axelrod R. The evolution of cooperation. New York, NY: Basic Books, 1984. 